\title{
İnşaat Mühendisliği Öğrencilerinin Ana Bilim Dallarındaki Yeterlilikleri Üzerine Bir Araştırma: Mevcut Durum, Sorunlar ve Çözüm Önerileri
}

\author{
Fatih Karaçor ${ }^{*}$, Kaan Yünkül ${ }^{2}$, Ahmet Erdağ ${ }^{3}$ \\ * Gazi Üniversitesi Mühendislik Fakültesi İnşaat Mühendisliği Bölümü, Ankara, Türkiye (ORCID:0000-0003-1201-7857), fatihkaracor@gmail.com \\ ${ }^{2}$ Gazi Üniversitesi Mühendislik Fakültesi İnşaat Mühendisliği Bölümü, Ankara, Türkiye (ORCID:0000-0003-1264-237X), kaanyunkul@gazi.edu.tr \\ ${ }^{3}$ Gazi Üniversitesi Teknoloji Fakültesi İnşaat Mühendisliği Bölümü, Ankara, Türkiye (ORCID: 0000-0001-9380-9439), ahmeterdag@gazi.edu.tr
}

(İlk Geliş Tarihi 20 Ekim 2021 ve Kabul Tarihi 21 Aralık 2021)

(DOI: 10.31590/ejosat.1012610)

\begin{abstract}
ATIF/REFERENCE: Karaçor, F., Yünkül, K. \& Erdağ, A. (2021). İnşaat Mühendisliği Öğrencilerinin Ana Bilim Dallarındaki Yeterlilikleri Üzerine Bir Araştırma: Mevcut Durum, Sorunlar ve Çözüm Önerileri. Avrupa Bilim ve Teknoloji Dergisi, (31), 545-552.

$\ddot{O} \mathbf{z}$

İnşaat mühendisliği öğrencilerinin lisans eğitimlerinde almış oldukları bitirme projesi ve yaz stajı dersi, gelecekteki çalışma hayatları hakkında ön fikir oluşturmaktadır. Geleneksel olarak lisans eğitimlerinde dinleyici konumda bulunan öğrenciler yaz stajı ve bitirme projesi dersi sayesinde mesleki çalışma koşullarını deneyimlemekte, ayrıca mesleki anlamda eksiklerini tamamlamakta ve inşaat mühendisliği problemlerini araştırarak çözüm yolları bulmayı aktif olarak öğrenmektedirler. Bu çalışma ile yaz stajı ve bitirme projesi dersleri almış olan inşaat mühendisliği öğrencilerinin, pasif öğrenme yolu ile teorik olarak aldıkları derslerin yaz stajı ve bitirme projesine etkisi, mesleki eksiklerinde farkındalıklar, yaz stajı ve/veya bitirme projesi derslerinin gelecekteki kariyer ve akademik tercihlere etkisi incelenmiştir. Bu amaçla Gazi Üniversitesi Mühendislik Fakültesi ve Teknoloji Fakültesi İnşaat Mühendisliği Bölümlerinde 2018-2020 yılları arasında bitirme projesi dersini alan 340 öğrenciye anket çalışması yapılmıştır. Anketlerin değerlendirilmesi sonucunda öğrencilerin zorunlu olan staj sayılarının arttırılarak daha fazla alan ve tecrübe kazanmaları amacıyla çalı̧̧ma tecrübesi olan insanlar tarafindan düzenlenecek sempozyumlara daha fazla ihtiyaç duyulduğu sonucu elde edilmiştir.
\end{abstract}

Anahtar Kelimeler: İnşaat mühendisliği, Eğitim, Bitirme projesi, Yaz staj1

\section{A Research on the Competences of Civil Engineering Students in Departments: Current Situation, Problems and Solution}

\begin{abstract}
An initial comprehension of professional civil engineering is generated in the minds of civil engineering students via the graduation project and the summer internship course. In the conventional undergraduate education, students have a passive role as listeners; however, thanks to the summer internship and the graduation project, they are provided the opportunity to actively search for solutions by investigating the conditions in their work environment, the engineering problems, and their professional deficiencies. In this study, the contributions of theoretical courses, which were based on passive learning, to the performances of the students during their summer internship and graduation project were investigated. Moreover, the effect of the summer internship and/or graduation project courses on the awareness of their professional deficiencies, future careers, and academic preferences were also examined. For this purpose, a questionnaire was designed for 340 students who completed the graduation project course between 2018-2020 at Gazi University Engineering Faculty and Technology Faculty Civil Engineering Departments. The findings of the questionnaire showed that the number of compulsory internships should be increased for students and there is a need for seminars organized by highly experienced professionals from diverse technical areas, in order to give students more experience on different areas.
\end{abstract}

Keywords: Civil engineering, Education, Graduation project, Summer internship 


\section{Giriş}

Tarihi insanlık tarihine dayanan inşaat mühendisliği; binalar, yollar, köprüler, tüneller, barajlar, havaalanları, demiryolları, istinat yapıları, kanalizasyon sistemleri, sulama sistemleri gibi fiziksel veya doğal yapıların tasarımı, inşası, tamiri, bakımı, onarımı ve maliyeti ile ilgilenen bir mühendislik disiplinidir. İnşaat mühendisliği eğitiminin en temel hedeflerinden birisi, gelişen ve ilerleyen çağa ayak uyduran ve toplumun ihtiyaçlarını karşılayabilen mühendis adaylarının mesleki yeterliliklerini geliştirmektir (Kaya vd., 2017). Mesleki yeterliliğe sahip inşaat mühendisleri yetiştirilmesi için, inşaat mühendisliği lisans eğitiminin; teorik mühendislik bilgisi ve pratik mühendislik becerileri içermesi gerekmektedir. Teorik olarak inşaat mühendisliği temel bilim dallarından alınan (geoteknik, hidrolik, mekanik, ulaştırma, yapı, yapı malzemesi, yapım yönetimi vs.) eğitimlerinin yanı sıra, mühendis adayları pratik becerilerini geliştirmek için yaz stajı ve bitirme projesi uygulamalarına katılarak mesleklerini tanımaya çalışmaktadırlar.

Çoğu lisans eğitiminde olduğu gibi inşaat mühendisliği bölümünde de öğretim üyesi merkezli anlatım yöntemi kullanılmaktadır. Öğrenciler; dersin dinlenmesi, dersle ilgili not tutulması ve ögretim elemanı tarafindan önerilen referans kaynakların incelenmesi gibi aktiviteleri gerçekleştirmek ile sorumludur. $\mathrm{Bu}$ yönteme pasif öğrenim adı verilmektedir. Geleneksel öğrenimin bir parçası olan pasif öğrenim, öğrenci merkezli değil öğretim elemanı merkezlidir (Felder ve Brent, 2009; Bayram vd., 2011; Mertol ve Y1lmaz, 2011; Kaya vd. 2017). Pasif öğrenim yöntemi ile lisans öğrencileri bazı konuları daha yüzeysel olarak öğrenebilmektedir (Marton vd., 1984; Elshorbagy ve Schonwetter, 2002; Kaya vd. 2017). Bu yüzden bu öğrenim yönteminin tüm dersler ve branşlar için uygun olmayacağı ve sadece öğretim elemanın anlattığı ders dinlenerek öğrenilen bilgilerin kalıcı olmayacağı birçok araştırmacı tarafından belirtilmiştir (Ersoy, 2009; Soygür, 2009; Kaya vd. 2017). Diğer bir öğrenme yöntemi olan aktif öğrenme ile öğrencilerin konuları araştırılması, öğrenilmesi, yorumlanması doğrudan öğrenci tarafından gerçekleştirilerek, inşaat mühendisliği eğitimi daha etkin ve kalıcı olacaktır (Mertol ve Yılmaz, 2011; Kaya vd. 2017; Uğur, 2017; Demirtürk ve Tunç, 2021). Aktif öğrenme yöntemi ile öğrencilerin bilgiyi araştırarak öğrenmesinin yanı sıra, gerekli bilgisayar programlarını öğrenmekte ve teorik olarak öğrendikleri bilgileri uygulamada kullanabilmektedirler. $\mathrm{Bu}$ nedenle, inşaat mühendisliği mesleği ve günümüz teknolojisindeki değişimler göz önüne alındığında, öğrenciler aktif öğrenme yöntemleri ile öğrendikleri bilgileri meslek hayatlarında doğrudan kullanacaklardır. $\mathrm{Bu}$ sayede daha donanımlı inşaat mühendislerinin yetiştirilmesi mümkün olacaktır.

İnşaat mühendisliği lisans eğitimde bitirme projesi ve yaz stajı dersleri aktif öğrenme yöntemleri olarak gösterilmektedir. Bu dersler sayesinde mühendis adayları inşaat mühendisliği mesleğinin çalışma şartlarını (ofis/şantiye) deneyimlemekte, ekip çalışması yapabilmekte, mesleki anlamda eksikliklerini belirleyebilmekte, mesleki ihtiyaçlarını öğrenmekte ve mezuniyet sonrası geleceğe dair çalışma planlarını (akademik ve kariyer uzmanlık alanları) oluşturmaktadırlar. Ayrıca inşaat mühendisliği öğrencileri, çeşitli meslek odaları ve kurumlar tarafından verilen eğitimler ve sempozyumlara katılarak aktif olarak yeni ve güncel mühendislik bilgileri ögrenmektedirler.

Bu bağlam doğrultusunda, yapılan bu çalışmada öğrencilerin teorik ve pratik bilgilerinin yeterliliklerini etkileyen faktörler e-ISSN: 2148-2683 değerlendirilmiştir. Yaz stajı ve bitirme proje derslerinin öğrencilerin yeterliliklerine katkıları incelenmiştir. Öğrencilerin teorik ve pratik bilgi düzeylerinin yanı sıra; inşaat mühendisliği eğitimi için önerilere yer verilmiştir.

Çalışmada Gazi Üniversitesi Mühendislik Fakültesi ve Teknoloji Fakültesi İnşaat Mühendisliği bölümlerinde 2018-2020 öğrenim dönemlerinde bitirme projesi dersi alan 340 öğrenciye bir anket çalışması yapılmış olup elde edilen veriler istatistiksel olarak değerlendirilmiştir.

\section{Staj ve Bitirme Projesi Dersinin Amaç ve Önemi}

Yaz staj1, inşaat mühendisliği öğrencilerinin teorik olarak öğrendikleri bilgileri, iş hayatında karışılacakları problemlerin çözümde kullanarak ve mesleki etik kavramını yerinde gözlemleme şansını buldukları aktif öğrenme yöntemlerinden birisidir (King ve Duan, 2010; Koçyiğit vd., 2011). Yaz stajı sayesinde inşaat mühendisi öğrencileri, mesleki çalışma ortamlarını tanıyarak, çalışma (şantiye, ofis) koşulları ve uzmanlık alanları (geoteknik, hidrolik, mekanik, ulaştırma, yapı, yap1 malzemesi, yapım yönetimi) hakkında bir ön fikir veya tecrübe oluşturmaktadırlar. 2020 y1lı ÖSYM (Öğrenci Seçme ve Yerleştirme Merkezi) verilerine göre ülkemizde devlet ve vakıf üniversitelerine 7529 aday inşaat mühendisliği bölümüne Temel Yeterlilik Testi (TYT) ile 648 aday Mühendislik Tamamlama Sınavı ile 176 aday Dikey Geçiş Sınavı (DGS) ile üniversitelerin inşaat mühendisliği programlarına yerleşmişlerdir. İnşaat mühendisliği bölümüne yerleşen adayların sayısı 2016 yılına kadar artış gösterirken 2017 ve sonrasında önemli miktarda azalmalar meydana gelmiştir. Şekil 1.'de ülkemizdeki toplamda ve Gazi Üniversitesine son 5 yılda yerleşen inşaat mühendisliği öğrencilerinin sayısı verilmiştir. $\mathrm{Bu}$ azalmaların en önemli nedenleri 2016 yılına kadar ülkemizde birçok inşaat mühendisliği programlarının açılması, DGS ve mühendislik tamamlama kontenjanları ile mezun inşaat mühendislerinin sayısının ani artması ve bunun sonucunda teknik anlamda yetkin inşaat mühendislerinin sayısının azalması ve inşaat sektörünün ihtiyaçtan fazla mühendise sahip olması gösterilebilir. Tüm bu nedenler inşaat mühendisi adaylarının, mesleki anlamda kendilerini yetiştirebilecekleri staj yeri bulma olasılığını azaltmaktadır.

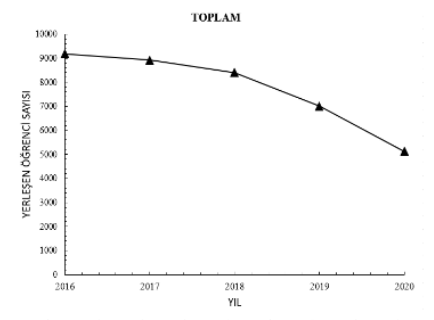

(a)

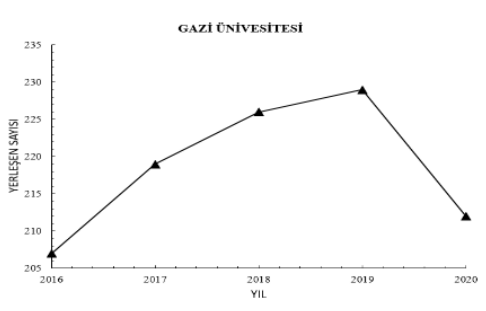

(b)

\section{Şekil 1. Son 5 yll içerisinde inşaat mühendisliği bölümüne yerleşen öğrenci sayıları; (a): toplam yerleşen (b): Gazi üniversitesi'ne yerleşen}

Ülkemizde inşaat mühendisliği öğrencilerinin yaz stajı ile karşılaştıkları sorunlar literatürde eksikliğini korumaktadır. Fakat yapılan çalışmalar incelendiğinde; inşaat mühendisliği bölümlerinin öğrencilere yaz stajı yeri bulma konusunda gereken desteği sağlayamadığı, özellikle meslek odaları ile bağlantılarının 
yeterli düzeyde olmadığı (Oğuz vd., 2009), mühendislik fakültelerinin ve/veya inşaat mühendisliği bölümlerinin sektördeki firmalar ile olan bağlantı eksiklikleri (Kayıkçı, 2009), öğrencilerin yaz stajı dersi hakkındaki bilgi eksikleri ve yaz stajı yapılan firmanın ve/veya yapılan işin denetiminde olan eksikler (Koçyiğit vd., 2011), başlıca öğrencilerin karşılaştıkları sorunlardır.

İnşaat mühendisliği lisans eğitiminde kullanılan bir diğer aktif ögrrenme yöntemi ise bitirme projesi dersidir. Bu ders kapsamında öğrenciler; karşılaşılacak inşaat mühendisliği problemlerinin çözümünde; deneysel, nümerik veya analitik yöntemler ile öğrenme becerilerini geliştirmektedirler (Kaya vd., 2017). Öğrenciler verilen ödev konusu hakkında gerekli literatür araştırması yapma, laboratuvar deney sonuçlarını yorumlama, ilgili paket programlar kullanarak problem çözme ve zaman yönetimi becerilerini geliştirmektedirler. Ayrıca öğrenciler, tez yazım formatını öğrenmekte ve proje sunumu ile sunum becerilerini geliştirmektedirler. Ülkemizde inşaat mühendisliği öğrencilerinin bitirme projesi dersinde karşılaştıkları zorluklar; piyasada kullanılan paket programlar ve programlama dillerinde olan eksiklikleri, literatür tarama becerilerinin gelişmemesi ve tez yazım kurallarına hakim olamamaları şeklinde özetlenmektedir (Kaya vd., 2017).

\section{Araştırmanın Amacı}

Çalışmanın amacı; inşaat mühendisliği bölümü öğrencilerinin öğrenim yeterlilikleri ve bu yeterliliklere yaz staj1 ve bitirme projesi dersinin etkisinin belirlenmesidir. Ayrıca öğrencilerin gelecekte çalışma alanı olarak önde gördükleri bilim dallarını incelemektir. Bu amaçla yetkinlik puanlarına etki eden faktörleri belirlemek için kurulan hipotezlerin numaralandırılması Tablo 1'de verilmiştir.

Tablo 1. Kurulan hipotezler

\begin{tabular}{|l|l|l|l|l|l|}
\hline Hipotez & Yetkinlik Puanı & Hipotez & Yetkinlik Puanı & Hipotez & Yetkinlik Puanı \\
\hline H1 & Cinsiyet & $H 6$ & Şantiye Stajı Bilim Dalı & H11 & Üniversitede Sempozyum \\
\hline H2 & Yaş & $H 7$ & Ofis Stajı Bilim Dalı & H12 & Paket Program Yetkinliği \\
\hline H3 & Şantiye Stajl & $H 8$ & Bitirme Ödevi Bilim Dalı & H13 & Paket Program Talebi \\
\hline H4 & Ofis Stajl & $H 9$ & Lisansüstü Tercihi & H14 & Kariyer Günleri Talebi \\
\hline H5 & Bitirme Ödevi & H10 & Sempozyumlara Katılım & H15 & Üniversitenin Staj Imkânı \\
\hline
\end{tabular}

\section{Yöntem}

\subsection{Araştırma Modeli}

$\mathrm{Bu}$ araştırma tarama modelindedir ve inşaat mühendisliği öğrencilerinin inşaat mühendisliği ve ana bilim dallarındaki yetkinlik puanlarının çeşitli değişkenler açısından incelemeyi amaçlamaktadır.

\subsection{Evren ve Örneklem}

Çalışmanın evreni Gazi Üniversitesi İnşaat Mühendisliği öğrencileridir. Yapılan çalışma kapsamında 2018-2019 ve 20192020 Bahar ve Güz Dönemlerinde Gazi Üniversitesi Mühendislik Fakültesi ve Teknoloji Fakültesi İnşaat Mühendisliği Bölümlerinde bitirme projesi dersini alan ve başarılı şekilde bitiren 340 öğrenciye gönüllülük esasına göre yüz yüze ve pandemi döneminde ise online (Google Formlar) olarak anket çalışması yapılmıştır.

\subsection{Veri Toplama Araçları}

Yapılmış olan anketin ilk bölümünde öğrencilere ait sosyodemografik sorular sorulmuştur. Anketin ikinci bölümünde her bir katılımcının her bir soruya karşı gösterdiği tutumu belirleyen, Rensis Likert tarafından önerilen Likert ölçeği kullanılmıştır (Likert, 1932). Beşli Likert ölçeği 1-5 aralığında değerler ve bu değerlere karşılık gelen değerlendirme kriterlerinden oluşmaktadır. Katılımcılara yöneltilen sorularda 1-Kesinlikle katılmiyorum, 2-Katılmiyorum, 3-Kararsızım, 4-Katılıyorum ve 5-Kesinlikle Katılıyorum seçenekleri sunulmuştur.

\subsection{Verilerin Analizi}

Verilerin analizinde "MS Excel 2018" ve "SPSS v22.0" programları kullanılmıştır. Yetkinlik puanlarının ortalamaları karşılaştırılmıştır. Kategori sayısı iki olan hipotezlerde Bağımsız Örnekler T Testi (Independent Samples T-Test), kategori sayıs ikiden fazla olan hipotezlerde ise Tek Yönlü Anova Testi (OneWay Anova) testleri kullanılmıştır. Yapılan bütün analizlerde anlamlılık düzeyi $\mathrm{p}=0.05$ olarak alınmıştır.

\section{Bulgular}

Yapılan anket çalışmasında Gazi Üniversitesi Mühendislik Fakültesi ve Teknoloji Fakültesi İnşaat Mühendisliği Bölümü öğrencilerinin lisans eğitimlerinde aldıkları derslerin bitirme projesi dersi ve yaz stajına etkisi, inşaat mühendisliği mesleki eksikliklerinde farkındalıklar, bitime projesi ve yaz stajının inşaat mühendisi adayı öğrencilerin gelecek kariyer ve akademik tercihlerine etkisi amaçlandığı çalışmaya 340 öğrenci katılmıştır.

Katılımcıların yaş ve cinsiyet dağılımları Şekil 2.'de verilmiştir. Cinsiyet dağılımı 76 kadın ve 264 erkek olarak görülmüştür. Yaş dağılımı ise 292 kişi 20-24 yaş arası, 40 kişi 2430 yaş aralığında ve 8 kişide 30 yaş üstü olduğu görülmüştür.

Öğrencilerin yaz stajı (ofis/şantiye), bitirme projesi ve gelecekteki yapmak istedikleri yüksek lisans eğitimleri tercih ettikleri bilim dalları incelenmiştir. Elde edilen veriler doğrultusunda ülkemizde günümüzde çalışma alanı ve/veya gelecekte çalışma alanı olabilecek bilim dalları belirlenmiştir (Şekil 3). Bu bölümde elde edilen sonuçlar ile öğrencilerin yaz stajı ve bitirme projesi için tercih ettikleri bilim dalları arasında farklılıklar gözlemlenmiştir. 


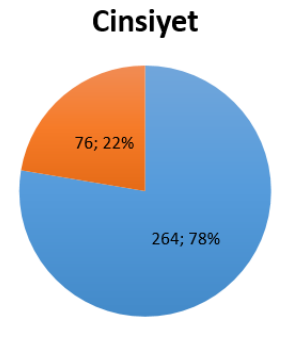

m Erkek $=$ Kadı

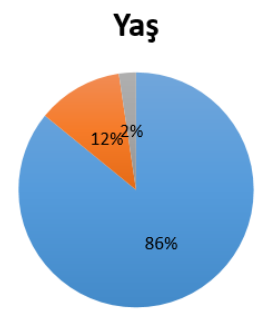

- 20-24 $=24-30=30$ Üstü

(b) (a)

Şekil 2. Katılımcı öğrencilerin dă̆ılımlar; (a): yaş, (b): cinsiyet

Ankette bulunan sosyo-demografik sorulara verilen cevapların dağılımı Tablo 2.'de verilmiştir. Katılımcıların 228

Şantiye Stajı

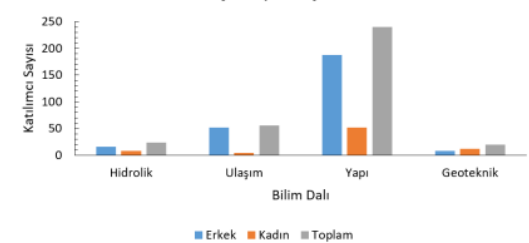

(a)

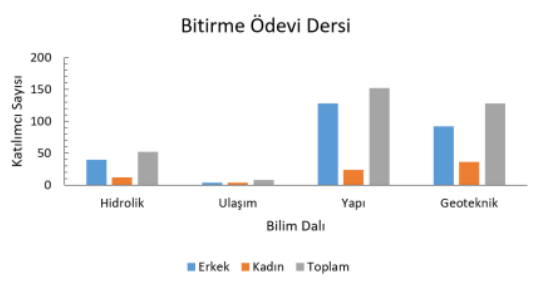

(c)
$(\% 67,06)$ 'i verilen eğitim ve sempozyumlara katılmaktadır. Öğrencilerin \%34.12'si inşaat sektöründe kullanılan paket programlarda yeterli bilgiye sahip olduklarını belirtmişlerdir. \%98,82'si ise bu paket programların lisans eğitimi süresince verilmesini istemektedirler.

Yaz stajı ve bitirme projesinin öğrencilerinin eksikliklerinde farkındalıklarını ve gelecekteki çalışmak isteyecekleri bilim dallarına etkisini araştırmak amacıyla; katılımcılara yaz stajı ve bitirme projesi derslerini hangi bilim dallarında yaptıkları, ofis çalışma hayatı için gerekli program bilgileri, yapılan mesleki sempozyum ve kariyer günlerine katılma durumları ve gelecekte çalışmak istedikleri bilim dalı hakkında sorular sorulmuş. Tablo 3'de katılımcıların teorik ve pratik yetkinliklerini ölçmeye yönelik sorulan sorulara verilen cevapların dağılımı verilmiştir.

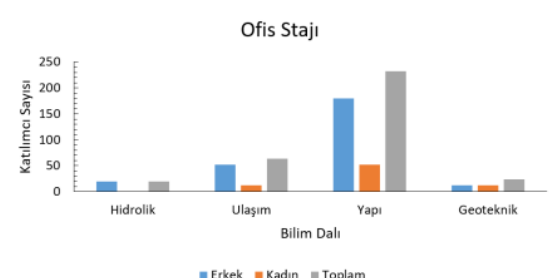

(b)

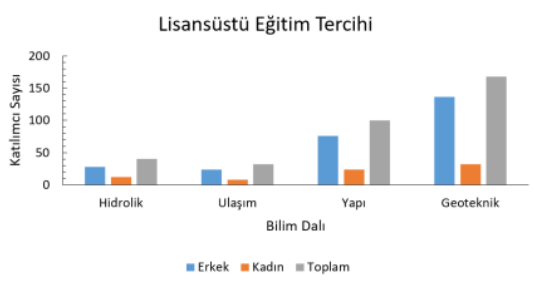

(d)

Şekil 3. Öğrencilerin cinsiyetlerine göre bilim dalları tercihleri; (a): şantiye stajı, (b): ofis stajı, (c): bitirme projesi dersi, (d) lisansüstü eğitim Tercihleri

Tablo 2. Anketteki sosyo-demografik sorulara verilen cevapların dă̆ılımı

\begin{tabular}{|l|l|l|}
\hline Sorular & Seçenekler & $\boldsymbol{n}(\%)$ \\
\hline \multirow{2}{*}{ Cinsiyet } & Erkek & $264(\% 77,6)$ \\
\cline { 2 - 3 } & Kadın & $76(\% 22,4)$ \\
\hline \multirow{3}{*}{ Yaş } & $20-24$ & $292(\% 85,9)$ \\
\cline { 2 - 3 } & $25-30$ & $40(\% 11,8)$ \\
\cline { 2 - 3 } Şantiye stajını yaptınız mı? & 30 Üstü & $8(\% 2,4)$ \\
\hline \multirow{2}{*}{ Ofis stajını yaptınız mı? } & Evet & $324(\% 95,3)$ \\
\cline { 2 - 3 } & Hayır & $16(\% 4,7)$ \\
\hline \multirow{2}{*}{ Bitirme ödevi dersini aldınız mı? } & Evet & $244(\% 71,8)$ \\
\cline { 2 - 3 } & Hayır & $96(\% 28,2)$ \\
\hline \multirow{5}{*}{ Şantiye stajınızı hangi bilim dalında yaptınız? } & Evet & $328(\% 96,5)$ \\
\cline { 2 - 3 } & Hayır & $12(\% 3,5)$ \\
\cline { 2 - 3 } & Hidrolik & $24(\% 7,1)$ \\
\cline { 2 - 3 } & Yapı & $240(\% 16,5)$ \\
\cline { 2 - 3 } & Geoteknik & $20(\% 5,9)$ \\
\hline \multirow{5}{*}{ Ofis stajınızı hangi bilim dalında yaptınız? } & Hidrolik & $20(\% 5,9)$ \\
\cline { 2 - 3 } & Ulaşım & $64(\% 18,8)$ \\
\cline { 2 - 3 } & Yapı & $232(\% 68,2)$ \\
\cline { 2 - 3 } & Geoteknik & $24(\% 7,1)$ \\
\hline
\end{tabular}


Tablo 3. Katılımcıların anabilim dalı ve bilim dallarındaki yetkinlikleri

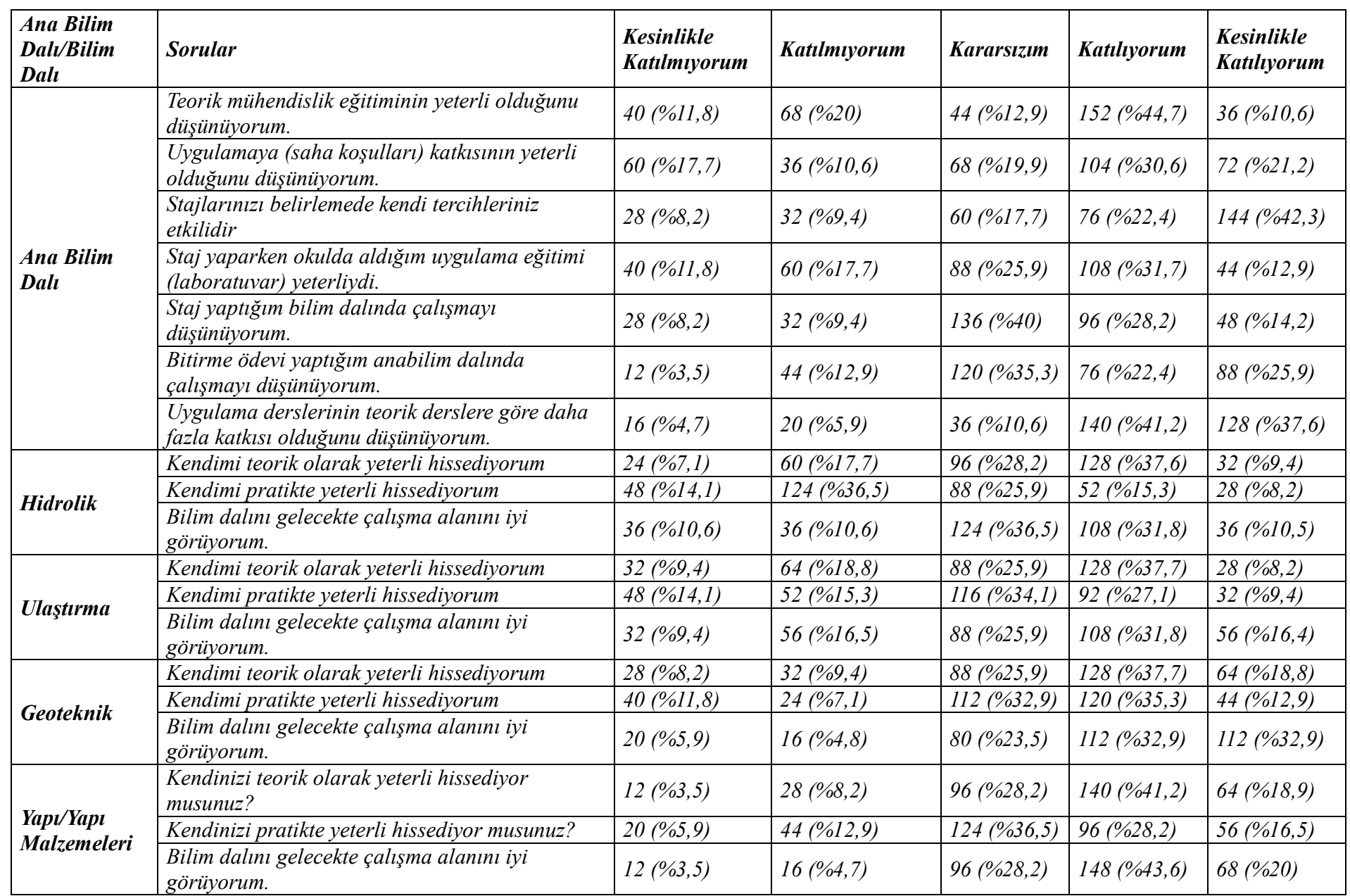

Katılımcıların yetkinlik puanlarının sosyo-demografik özelliklerle karşılaştırılması Tablo 4'de gösterilmiştir. Katılımcıların bilim dallarına göre ortalama puanları Tablo 5.'de verilmişsir.

Katılımcıların yetkinlik puanlarının $(\mathrm{Y})$ sosyo-demografik sorulardan;

Yaş grupları ile kıyaslandığında $20-24$ yaş $(63,66 \pm 12,17), 25$ 30 yaş $(65,90 \pm 13,03)$ ve 30 üstü $(79,00 \pm 12,83)$ istatistiksel olarak anlamlı şekilde fark çıkmışıı $(\mathrm{p}=0,002)$.

Şantiye stajı yapma durumu ile kıyaslandığında yapanların $(64,68 \pm 12,57)$ ve yapmayanların $(56,25 \pm 6,90)$ puanları arasında istatistiksel olarak anlamlı fark tespit edilmiştir $(\mathrm{p}=0,008)$.

Ofis stajı yapma durumu ile kıyaslandığında yapanların $(65,92 \pm 12,8)$ ve yapmayanların $(60,13 \pm 10,61)$ puanları arasında istatistiksel olarak anlamlı fark tespit edilmiştir $(\mathrm{p}<0,001)$.

Şantiye stajlarını yaptıkları bilim dalı "Hidorilik" $(60,17 \pm 8,03)$, "Ulaşım" $(64,14 \pm 11,45)$, "Yapı" $(63,77 \pm 12,41)$ ve "Geoteknik" $\quad(75,80 \pm 14,85)$ olanların puanları arasında istatistiksel olarak anlamlı fark vardır $(\mathrm{p}<0,001)$.

Lisansüstü eğitim tercihleri olan bilim dalı "Hidrolik" $(52,70 \pm 15,6)$, "Ulaşım" (65,38 $\pm 15,71)$, "Yapı" $(63,68 \pm 11,65)$ ve "Geoteknik" $(67,19 \pm 9,6)$ olanların puanları arasında istatistiksel olarak anlamlı fark vardır $(\mathrm{p}<0,001)$.
$\mathrm{Bu}$ eğitimler verilmiyorsa üniversitemiz bünyesinde verilmesi ister misiniz sorusuna "Evet" diyenler $(64,68 \pm 11,73)$ ve "Hayır" $(59,00 \pm 19,55)$ diyenlerin puanları arasında istatistiksel olarak anlamlı fark vardır $(\mathrm{p}<0,001)$.

Katılımcıların mezun olduklarında kendilerini inşaat mühendisliği paket programlarında yeterli hissetme durumlarına göre "Evet" diyenler $(69,55 \pm 14,63)$ ve "Hayır" $(61,55 \pm 10,22)$ diyenlerin puanları arasında istatistiksel olarak anlamlı fark vardır $(\mathrm{p}<0,001)$.

Üniversitemiz bünyesinde inşaat mühendisliğinde kullanılan paket programları eğitimi verilmesini ister misiniz sorusuna "Evet" diyenler $(64,37 \pm 12,53)$ ve "Hayır" $(57,00 \pm 0,00)$ diyenlerin puanları arasında istatistiksel olarak anlamlı fark vardır $(\mathrm{p}<0,001)$.

Üniversitemiz bünyesinde inşaat firmalarının katılımı ile gerçekleştirilen kariyer günlerini yeterli buluyor musunuz sorusuna "Evet" diyenler $(69,26 \pm 14,75)$ ve "Hayır" $(62,85 \pm 11,38)$ diyenlerin puanları arasında istatistiksel olarak anlamlı fark vardır $(\mathrm{p}<0,001)$.

Üniversite size staj bulma konusunda fayda sağlanıp sağlanmdığı soruldugunda "Evet" diyenler $(69,92 \pm 12,87)$ ve "Hayır" $(61,80 \pm 11,48)$ diyenlerin puanları arasinda istatistiksel olarak anlamlı fark vardır $(\mathrm{p}<0,001)$.

Anketimizi değerlendirmenin güvenirliliği için Cronbach Alpha testi kullanılmıştır. Bu testte kullanılan (Özdamar, 2002) 
tarafından önerilen cr $\alpha$ katsayıları için güven aralıkları ve yorumları Tablo 6'da verilmiştir. Yapılan analiz sonucunda anketimizin cra katsayısı 0,887 olarak bulunmuştur. Ölçeğimiz yüksek güvenilirlik sınırları içerisindedir. Kurulan hipotezlerin sonuçları Tablo 7.'de verilmiştir.

Tablo 4. Katılımcıların yetkinlik puanlarının sosyo-demografik sorulara göre karşılaştırılması

\begin{tabular}{|c|c|c|c|}
\hline \multirow[b]{2}{*}{ Sorular } & \multicolumn{3}{|c|}{ Yetkinlik Puanı (Y) } \\
\hline & Seçenekler & Ort $\pm S S$ & $p$ \\
\hline \multirow{2}{*}{ Cinsiyet } & Erkek & $63,88 \pm 13,34$ & \multirow{2}{*}{0,168} \\
\hline & Kadın & $65,68 \pm 8,83$ & \\
\hline \multirow{3}{*}{ Yaş } & $20-24$ & $63,66 \pm 12,17$ & \multirow{3}{*}{$0,002 *$} \\
\hline & $25-30$ & $65,90 \pm 13,03$ & \\
\hline & $30 \ddot{U} s t \ddot{~}$ & $79,00 \pm 12,83$ & \\
\hline \multirow{2}{*}{ Şantiye stajını yaptınız mı? } & Evet & $64,68 \pm 12,57$ & \multirow{2}{*}{$0,008 *$} \\
\hline & Hayır & $56,25 \pm 6,90$ & \\
\hline \multirow{2}{*}{ Ofis stajını yaptınız mı? } & Evet & $65,92 \pm 12,8$ & \multirow{2}{*}{$<0,001^{*}$} \\
\hline & Hayır & $60,13 \pm 10,61$ & \\
\hline \multirow{2}{*}{ Bitirme ödevi dersini aldınız mı? } & Evet & $64,50 \pm 12,54$ & \multirow{2}{*}{0,093} \\
\hline & Hayır & $58,33 \pm 9,43$ & \\
\hline \multirow{4}{*}{ Şantiye stajınızı hangi bilim dalında yaptınız? } & Hidrolik & $60,17 \pm 8,03$ & \multirow{4}{*}{$<0,001 *$} \\
\hline & Ulaşım & $64,14 \pm 11,45$ & \\
\hline & Yapl & $63,77 \pm 12,41$ & \\
\hline & Geoteknik & $75,80 \pm 14,85$ & \\
\hline \multirow{4}{*}{ Ofis stajınızı hangi bilim dalında yaptınız? } & Hidrolik & $70,20 \pm 11,74$ & \multirow{4}{*}{0,114} \\
\hline & Ulaşım & $64,31 \pm 9,44$ & \\
\hline & Yapl & $63,55 \pm 13,14$ & \\
\hline & Geoteknik & $66,33 \pm 12,79$ & \\
\hline \multirow{4}{*}{ Bitirme ödevini hangi bilim dalında yaptınız/yapıyorsunuz? } & Hidrolik & $62,46 \pm 11,24$ & \multirow{4}{*}{0,322} \\
\hline & Ulaşım & $61,00 \pm 4,28$ & \\
\hline & Yapl & $65,55 \pm 15,41$ & \\
\hline & Geoteknik & $63,72 \pm 8,81$ & \\
\hline \multirow{4}{*}{ Lisansüstü eğitim yaparsanız hangi bilim dalını tercih edersiniz? } & Hidrolik & $52,70 \pm 15,6$ & \multirow{4}{*}{$<0,001 *$} \\
\hline & Ulaşım & $65,38 \pm 15,71$ & \\
\hline & Yapl & $63,68 \pm 11,65$ & \\
\hline & Geoteknik & $67,19 \pm 9,6$ & \\
\hline \multirow{2}{*}{$\begin{array}{l}\text { Çeşitli kurumlar tarafindan verilen eğitimler veya sempozyumlara katıllyor } \\
\text { musunuz? }\end{array}$} & Evet & $65,63 \pm 14,11$ & \multirow{2}{*}{$0,001 *$} \\
\hline & Hayır & $61,54 \pm 7,57$ & \\
\hline \multirow{2}{*}{ Ĕ̆er bu ĕgitimler verilmiyorsa üniversitemiz bünyesinde verilmesi ister misiniz? } & Evet & $64,68 \pm 11,73$ & \multirow{2}{*}{$<0,001 *$} \\
\hline & Hayır & $59,00 \pm 19,55$ & \\
\hline \multirow{2}{*}{$\begin{array}{l}\text { Mezun olduğunuzda kendinizi inşaat mühendisliği paket programlarında yeterli } \\
\text { hissediyor musunuz? }\end{array}$} & Evet & $69,55 \pm 14,63$ & \multirow{2}{*}{$<0,001 *$} \\
\hline & Hayır & $61,55 \pm 10,22$ & \\
\hline \multirow{2}{*}{$\begin{array}{l}\text { Üniversitemiz bünyesinde inşaat mühendisliğinde kullanılan paket programları } \\
\text { eğitimi verilmesini ister misiniz? }\end{array}$} & Evet & $64,37 \pm 12,53$ & $<0,001 *$ \\
\hline & Hayır & $57,00 \pm 0,00$ & \\
\hline Üniversitemiz bünyesinde inşaat firmalarının katılımı ile gerçekleştirilen kariyer & Evet & $69,26 \pm 14,75$ & $<0001 *$ \\
\hline günlerini yeterli buluyor musunuz? & Hayır & $62,85 \pm 11,38$ & \\
\hline Üniversite size stai hulma konusunda favda să̆ladiŏg mi? & Evet & $69,92 \pm 12,87$ & $<0,001 \%$ \\
\hline & Hayır & $61,80 \pm 11,48$ & \\
\hline
\end{tabular}

Tablo 5. Katılımcı öğrencilerin anabilim dalı yetkinliklerinin ortalama ve standart hata değerleri

\begin{tabular}{|l|c|c|c|}
\hline \multirow{2}{*}{ Yetkinlik } & \multicolumn{3}{|c|}{ (Ortalama/Standart Hata) } \\
\cline { 2 - 4 } & Teorik & Pratik & Gelecekteki Çalışma Alanı \\
\hline Hidrolik & $3.25 / 0.06$ & $2.67 / 0.06$ & $3.21 / 0.06$ \\
\hline Ulaştırma & $3.16 / 0.06$ & $3.31 / 0.06$ & $3.29 / 0.06$ \\
\hline Geoteknik & $3.49 / 0.06$ & $3.31 / 0.06$ & $3.82 / 0.06$ \\
\hline Yapı/Yapı Mekaniği & $3.64 / 0.05$ & $3.36 / 0.06$ & $3.72 / 0.05$ \\
\hline
\end{tabular}


Tablo 6. Cronbach alpha katsaylsl (cra) ve güven aralıkları

\begin{tabular}{|c|c|}
\hline Cronbach Alpha Katsayıs & Yorum \\
\hline $0.81<c r \alpha<1.00$ & Yüksek Güvenilirlik \\
\hline $0.61<c r \alpha<0.80$ & Orta Güvenilirlik \\
\hline $0.41<c r \alpha<0.60$ & Düşük Güvenilirlik \\
\hline $0.00<c r \alpha<0.40$ & Güvenilir Değil \\
\hline
\end{tabular}

Tablo 7. Hipotez sonuçları

\begin{tabular}{|c|c|c|c|c|c|}
\hline Hipotez & $\begin{array}{c}\text { Kabul Edildi / Kabul } \\
\text { Edilmedi }\end{array}$ & Hipotez & $\begin{array}{c}\text { Kabul Edildi / Kabul } \\
\text { Edilmedi }\end{array}$ & Hipotez & $\begin{array}{c}\text { Kabul Edildi / Kabul } \\
\text { Edilmedi }\end{array}$ \\
\hline$H 1$ & Kabul Edilmedi & H6 & Kabul Edildi & $H 11$ & Kabul Edildi \\
\hline$H 2$ & Kabul Edildi & $H 7$ & Kabul Edilmedi & H12 & Kabul Edildi \\
\hline$H 3$ & Kabul Edildi & $H 8$ & Kabul Edilmedi & $H 13$ & Kabul Edildi \\
\hline$H 4$ & Kabul Edildi & H9 & Kabul Edildi & H14 & Kabul Edildi \\
\hline$H 5$ & Kabul Edilmedi & H10 & Kabul Edildi & H15 & Kabul Edildi \\
\hline
\end{tabular}

\section{Sonuç ve Öneriler}

Bu çalışmada, Gazi Üniversitesi Mühendislik Fakültesi ve Teknoloji Fakültesi İnşaat Mühendisliği öğrencilerinin teorik olarak aldıkları derslerin yaz stajı ve bitirme projesine etkisi, mesleki eksikliklerinde farkındalıklar, yaz stajı ve/veya bitirme projesi derslerinin gelecekteki kariyer ve akademik tercihlerine etkisi anket çalışması ile incelenmiştir. Yaz stajı ve/veya bitirme projesi derslerinin öğrenciler veya inşaat mühendisliği mesleğine yeni başlayan mühendisler için neden faydalı olduğu konusunda bazı çıkarımlar aşağıda sunulmuştur.

- Mühendislik öğrencilerinin uzun kariyer hayatlarının ilk aşaması olarak görülen stajlar, gelecekteki mühendislik kariyerlerinde başarılı olabilmesi için önemli etkenlerden birisidir.

- Öğrenci, staj sırasında gerçek projeler üzerinde çalışır, mevcut piyasa trendlerini tanır, teknik becerilerini keskinleştirir ve talep üzerine teknik beceriler öğrenebilir. Bunun dışında staj, kurumsal dünyayla tanıştırır, mesleki etik öğretir, iletişim ve kişiler arası becerilerini parlatır. Bir staj ile, mezuniyetten öncesi bir mühendis tecrübesi kazanabilirler, bu da tam zamanlı bir işe girildiğinde çalışma ortamına zahmetsizce uyum sağlamak için son derece yardımcı olabilir.

- Staj deneyimi, beceri setini doğrular ve bu nedenle işe alım sürecini hızlandırır, yani bir işe yerleştirme/iş bulma şansını artırır. Ayrıca, önemli sayıda staj, öğrencinin yeteneklerini kanıtlama ve stajını tam zamanlı bir işe dönüştürme firsatı veren bir ön yerleştirme teklifi ile birlikte gelir. Bunun yanı sıra stajlar, gelecekte iş başvurusu yaparken işinize yarayabilecek profesyonel ağın oluşmasına olanak tanır.

- Her mühendislik dalı, geniş bir konu alanıdır. Ancak, işteyken yalnızca belirli alanlarda çalışılması gerekmektedir.
Örneğin, bir inşaat mühendisi, köprü, akarsu, tünel, yazılım geliştirme veya diğer konularında uzmanlaşılabilir. Stajlar ve bitirme projeleri sayesinde, öğrenciye branşının farklı yönlerini keşfetme firsatı sunar ve bir iş veya yükseköğrenim için en uygun alanı seçmesine yardımcı olur.

- Bir öğrenci bitirem projesi ve yaz stajında, yalnızca kendi alanlarında derinlemesine bilgi ve deneyim kazanmaz, aynı zamanda başkalarıyla bir ekipte nasıl çalışılacağını, diğer üyelerle işbirliğini, araştırma yapmayı, problemlere çözüm yolu bulmayı ve zaman yönetimini öğrenir.

- Stajlar ve bitirme projeleri, öğrencilerin eğitim süreleri boyunca hatalarından ders almalarına yardımcı olan aktif öğrenme yöntemlerindendir. Hatalarından öğrenmek, sonunda tam zamanlı bir iş rolüne geçiş yaparken onlar için gerçekten yardımcı olabilecek becerilerini geliştirir. İş rollerinde iyi performans göstermeleri için öğrenmeleri gereken güçlü, zayıf, bilgi veya becerilerini bilmelerine yardımcı olur.

Elde edilen istatiksel sonuçlar doğrultusunda, öneriler aşağıda sunulmuştur.

- İnşaat Mühendisliği lisans eğitiminde mezuniyet şartı olarak iki farklı dönemde yaptıkları yaz stajı yerine, her bilim dalından ayrı ayrı staj yapmaları istenmelidir. Bu sayede mesleki anlamda daha yetkin ve gelecekte çalışma alanı hakkında daha detaylı ön fikre sahip olan mühendis adayları yetişebilecektir.

- Yukarıdaki önerinin gerçekleşmesi için öğretim üyelerinin de içerisinde bulunduğu, aktif bir mezun iletişim sistemi kurularak, öğrencilere staj yeri bulma konusunda destek verilmelidir. Sonuçlarda da belirtildiği gibi, staj yeri bulma 
konusunda üniversiteden destek bulan öğrencilerin yetkinlikleri yüksektir. Bu sayede yetkinliğin artacağı düşünülmektedir.

- Sempozyum ve kariyer günleri artırılarak ve yüksek katılım sağlanmasının yetkinliği artıracağı düşünülmektedir.

\section{Teşekkür}

Bu çalışmaya verdikleri destekten dolayı Gazi Üniversitesi Mühendislik Fakültesi İnşaat Mühendisliği Bölüm Başkanı Prof. Dr. Kurtuluş SOYLUK'a, Gazi Üniversitesi Teknoloji Fakültesi İnşaat Mühendisliği Bölüm Başkanı Prof. Dr. Salih YAZICIOĞLU'na ve ankete katılan öğrencilerimize teşekkür ederiz.

\section{Kaynaklar}

Bayram, S., Dirikgil, T., Tantekin, G., Bulut, N., Haktanır, T. ve Laptalı, E., (2011). İnşaat mühendisliği bölümü öğrencilerinin mevcut eğitim sistemine bakışı ve çözüm önerileri. 2. İş̧aat Mühendisliği Ĕ̆itimi Sempozyumu, Muğla, 265-274.

Demirtürk, D. ve Tunç, G., (2021). İnşaat mühendisliği eğitimi ve türkiye'de inşaat sektörünün lisans eğitimine bakış açısı. Engineering Sciences, 16 (1), 15-38.

Elshorbagy, A., ve Schonwetter, D.J., (2002). Engineer morphing: bridging the gap between classroom teaching and the engineering profession. International Journal of Engineering Education, 18 (3), 295-300.

Ersoy, U., (2009). İnşaat mühendisliği eğitiminde sorunlar, nedenleri ve çözüm yolları. 1. Inşaat Mühendisliği Eğitimi Sempozyumu, Ankara, 23-29.

Felder, R. ve Brent, R., (2009). Active learning: an introduction. ASQ Higher Education Brief, 1-5.

Kaya, N., Yünkül, K. ve Çiçek, C., (2017). İnşaat mühendisliği öğrencilerinin bitirme projelerinin öğrenci tercihleri ve önem derecesine göre değerlendirilmesi. 4. Inş̧aat Mühendisliği Ĕ̌itimi Sempozyumu, İzmir, 161-174.

Kayıkçı, N.S., (2009). İnşaat mühendisliği eğitimi ve sorunları. 1. İşaat Mühendisliği Eğitimi Sempozyumu, Antalya, 385-391.

King, W.S. ve Duan, L., (2010). Practical summer training in civil and construction engineering for cultivation of professional ability. Journal of Professional Issues in Engineering Education and Practice, 136, 4, 233-238.

Koçyiğit, Ö., Alyavuz, B. ve Bildirici, A., (2011). İnşaat mühendisliği eğitiminde staj. 2. Inşaat Mühendisliği Ĕ̆itimi Seтроzуити, Muğla, 235-246.

Likert, R.A., (1932). Technique for the measurement of attitudes. Archives of Psychology, 140, 44-55.

Marton, F., Hounsell, D. ve Entwistle, N.J., (1984). The Experience of Learning. Edinburgh Scottish Academic Press.

Mertol, H. ve Yılmaz, F., (2011). İnşaat mühendisliği eğitiminde aktif öğrenme yöntemlerinin gerekliliği, 2. Inşaat Mühendisliği Ĕgitimi Sempozyumu, Muğla, 265-274.

Oğuz, S. Altın, S., Yaman, İ.Ö., Kırçıl, M.S., Bakır, A. ve Sönmez, G., (2009). İnşaat mühendisliği eğitiminde Türkiye gerçeği. 1. Inşaat Mühendisliği Ĕ̈itimi Sempozyumu, Antalya, 207241.

e-ISSN: 2148-2683
Özdamar, K., (2002). Paket Programlarla İstatistiksel Veri Analizi-1. Kaan Kitabevi, Eskişehir.

Soygür, Ü., (2009). 21. yüzyılda inşaat mühendisi yetiştirmek ne öğretilmeli-nasıl öğretilmeli, 1. Inşaat Mühendisliği Eğitimi Seтроzуuтu, Ankara, 265-280.

Uğur, L.O., (2017). İnşaat mühendisliği eğitiminde, yapı işletmesi projesi dersi bünyesinde yapılan bir bilimsel makale hazırlama uygulaması ve getirileri. 4. Inşaat Mühendisliği Eğitimi Sempozyumu, İzmir, 150-160. 